\title{
Molecular Identification and Antibacterial Activity of Streptomyces spp. Isolated from Sulaymaniyah Governorate Soil, Iraqi Kurdistan
}

\author{
Syamand A. Qadir*, Osama H. Shareef, Othman A. Mohammed \\ Department of Medical Laboratory Science, Technical College of Applied Sciences, Sulaimani Polytechnic University, Halabja, Kurdistan \\ Region, Iraq
}

\author{
*Corresponding author: \\ Syamand A. Qadir, \\ Department of Medical \\ Laboratory Science, \\ Technical College of Applied \\ Sciences, Sulaimani \\ Polytechnic University, \\ Halabja, Kurdistan Region, \\ Iraq. \\ E-mail: syamand.qadir@ \\ spu.edu.iq
}

Received: 28 February 2020

Accepted: 11 May 2020

Published: 30 December 2020

\section{DOI}

10.25156/pti.v10n2y2020.pp119-125

\section{A B S T R A C T}

Soil is play an important role for reserve abundant groups of microorganisms, especially Streptomyces. Streptomyces are recognized as prokaryotes, aerobic and Gram-positive bacteria with high Guanine + Cytosine contents in their DNA. These groups of bacteria show filamentous growth from a single spore and they are normally found in all kinds of ecosystems, including water, soil, and plants. A total of three Streptomyces strains were isolated from soil of the sides of Darband Ranya in Sulaimani governorate. Different approaches were followed for the identification of the isolated stains. Morphological and cultural properties of these isolates have shown that the isolates are belonging to the genus Streptomyces. Desired colonies of the isolates were distinguished and separated from other bacteria on the basis of colony morphology, pigmentation, ability to produce a different color of aerial hyphae, and bottom mycelium on raffinose-histidine agar and starch-casein agar media. In addition, analysis of phylogenetic tree based on 16S rRNA gene sequences, the strains related the genus. KS010 isolates had the highest identity $(99.32 \%)$ with the type strain of Streptomyces atrovirens, while KSO05 and KS007 isolates were most closely related to Streptomyces lateritius by identity $99.32 \%$. The isolated test strains were also active against Gram-negative and Gram-positive pathogenic bacteria following co-cultivation technique. However, further study should be done to identify the types of these antibacterial compounds.

Keywords: 16S rRNA; Antimicrobial activity; Genomic DNA; Streptomyces; Tyndallization technique

\section{INTRODUCTION}

Streptomyces species are Gram-positive, aerobic, slow-grower bacteria that have filamentous morphology extensively branched substrate and aerial mycelia (Jüttner and Watson, 2007; Dyson, 2011). They produce and release spore after the segmentation of aerial hyphae (Glauert, 1961). The spore produces a wide range of pigments that they responsible for the color of the aerial mycelia and vegetative (Flärdh and Buttner, 2009).

Rather than the morphological characterization such color of spore or hyphae, Streptomyces bacteria can be identified by genomic analysis of $16 \mathrm{~S}$ rRNA, DNA-DNA hybridization, and the types of cell wall composition such as fatty acids, phospholipids, and peptidoglycan (KornWendisch and Kutzner, 1992). Streptomyces contains high guanine and cytosine contents (69-73.0\%) in their DNA sequence (Dastager and Sunil, 2016) while, interestingly, the origin of chromosomal replication is high in adenine and thymine contents (Ventura et al., 2007).
For the $1^{\text {st }}$ time, genus Streptomyces was introduced by Waksman and his colleague in 1943 (Waksman and Henrici, 1943). Streptomyces are able to live and grow in various habitats, soil is one of the best environment for its surviving and reproduction (Maleki et al., 2013; Mokrane et al., 2013; Hasani et al., 2014). This bacterium is defined as the largest diverse microorganism in soil that covers $40 \%$ of soil bacteria, while some biological, physical, and chemical factors are an effect on the distribution of Streptomyces in soil, including temperatures, $\mathrm{pH}$, salinity, moisture, soil texture, food stress, and climate. This genus has great economic and industrial importance since they produce valuable enzymes and about two-thirds of all-natural origin useful antibiotics (Hopwood, 2007; Belghit et al., 2016; Bunyapaiboonsri et al., 2016). Moreover, anti-parasite, immunosuppressant, antibacterial, and antifungal compounds have been identified as secondary metabolism products of Streptomyces (Sanghvi et al., 2014; Balachandran et al., 2015; Rambabu et al., 2015). High ratios $(75 \%)$ of bioactive medicinal and commercial beneficial molecules are produced by this type microorganism. Thus, researchers have focused on Streptomyces (Bérdy, 2005). 
Some species of Streptomyces have the ability to produce melanin that is important for protection against broken by chemical stress, high temperature, and biochemical threats (Madhusudhan et al., 2014).

The present study was aimed to isolate and characterize antibiotic producer Streptomyces from different soil samples collected at various unique environments of Darband Ranya in Sulaimani governorate because that place has not been investigated for isolation of Streptomyces and other Actinobacteria genera. Hence, it is really necessary to isolate Streptomyces from these soil samples so as to recover new Streptomyces species which produce antimicrobial compounds.

\section{MATERIALS AND METHODS}

\section{Soil Sampling and Isolation of Streptomyces spp.}

The sites of soil sample collection were in specific habitats of lakesides of Darband Ranya in Sulaimani governorate. Twelve soil samples were collected from the lakeside. To collect these samples, a sterile tubular was used from a depth of $15 \mathrm{~cm}$ after removing nearly $5 \mathrm{~cm}$ of the topsoil and placed the materials in sterile plastic bags. The samples were kept in a refrigerator $\left(4^{\circ} \mathrm{C}\right)$ until microbial assays were performed in Microbiology Laboratory for bacterial isolation. They were subjected for serial dilution up to $10^{-4}$ dilution.

Soil serial dilution plating technique $(0.1 \mathrm{ml}$ of dilution $10^{-3}$ and $10^{-4}$ ) was followed to isolate Streptomyces spp. starch casein agar medium supplemented with nystatin $(50 \mu \mathrm{g} / \mathrm{ml})$, cycloheximide $(50 \mu \mathrm{g} / \mathrm{ml})$, and novobiocin $(25 \mu \mathrm{g} / \mathrm{ml})$, and raffinose-histidine agar medium supplemented with nystatin $(50 \mu \mathrm{g} / \mathrm{ml})$ and cycloheximide $(50 \mu \mathrm{g} / \mathrm{ml})($ Vickers and Williams, 1987). Culture plates were incubated at $28^{\circ} \mathrm{C}$ for 7-10 days (Tatar and Sahin, 2015; Balachandran et al., 2016). Streptomyces strains were identified on the basis of their ability to utilize carbon and nitrogen sources, biochemical reactions, and amplification of the whole 16S rRNA gene. After incubation, colonies of Streptomyces were identified based on the pigmentation of the colonies and ability to produce a different color of aerial hyphae and substrate mycelium on each of Starch-casein agar and Raffinose-Histidine agar culture media. Desired colonies were distinguished and chosen for analyzing in detail.

\section{Chemotaxonomy and Morphology}

Morphology of the bacterial colonies was used as one of the crucial characters to identify the genus of Streptomyces. Among the similar color of colonies, only one colony was selected to study on. The bacterial colonies were streaked on Oatmeal agar to detect spore aerial hyphae, substrate mycelium color, and pigmentation of the diffusible pigments. Modified Bennett's agar was also used to obtain pure colonies from mix cultures.
A pure colony was suspended in $20 \%$ glycerol by scrapping the aerial and substrate mycelium from the modified Bennett's agar plates. The suspension was finally stocked at $-80^{\circ} \mathrm{C}$. Standard procedures were followed to detect isomers of diaminopimelic acid and sugar analysis (Staneck and Roberts, 1974).

\section{Nutritional tests on the isolated strains Nitrogen source}

It has been observed that the amount of antibiotic synthesis by the bacteria relates to each concentration and type of nitrogen source in their culture media (Rafieenia, 2013; Sánchez et al., 2010). Streptomyces species were checked for their ability to utilize nitrogen compounds such as potassium nitrate, L-tyrosine, and L-histidine. These compounds were sterilized by following Tyndallization technique (Atalan, 1993). The isolated strains were added to the sterilized nitrogen medium to give 0.1 concentrations $(\mathrm{W} / \mathrm{V})$. To test nitrogen utilization, the following media were used; basal medium contained L-Proline was used as a positive control and free nitrogen basal medium was used as a negative control. These media were incubated at $28^{\circ} \mathrm{C}$ for 4-7 days after inoculating the media with the bacterial strains and supplementing with desired nitrogen sources.

\section{Carbone source}

Glucose substrate becomes slow down the rate of antibiotic production growth (Lounes et al., 1996; Sánchez et al., 2010). The isolated strains were tested for their capability to use the following carbon sources; Dextran, D-Fructose, D-Mannitol, D-Raffinose, Lactose, Sucrose, Maltose, D-Mannose, Sodium acetate, and sodium citrate. These carbon sources were added to carbon utilization agar (ISP9). In addition to ISP9 medium, a basal medium contained D-glucose was used as a positive control and free basal medium used as a negative control. These media were inoculated with the desired isolates, incubated for $4-7$ days at $28^{\circ} \mathrm{C}$.

\section{Antimicrobial activity assay}

The following wild bacteria were used to check of antibacterial activity of the tested strains: Klebsiellapneumoniae, Staphylococcus aureus, Psendomonas fluorescens, Escherichia coli, and Bacillus subtilis (El-Naggar, 2015). Perpendiculars technique was followed to study the antibacterial activity of the isolates. In this method, the isolates were inoculated on Muller-Hinton agar and incubated at $28^{\circ} \mathrm{C}$ for $7-10$ days. The wild pathogenic strains were then streaked around the growth area of the isolates. The culture medium was incubated again at $37^{\circ} \mathrm{C}$ for up to $48 \mathrm{~h}$. Antibacterial producer isolates were able to inhibit the growth of the pathogenic strains and made a clear zone.

\section{Tolerance Tests}

The isolates were studied to investigate their ability to grow at $28^{\circ} \mathrm{C}$ in the modified Bennett's agar medium 
supplemented with the following chemical inhibitors; crystal violate $(0.0001 \%, \mathrm{w} / \mathrm{v})$ and sodium azide $(0.01 \%$, $\mathrm{w} / \mathrm{v})$. The culture medium was incubated for 7-10 days at $28^{\circ} \mathrm{C}$ and $50^{\circ} \mathrm{C}$ (Atalan, 1993).

\section{Molecular Characterization and Phylogenic Analysis of Streptomyces spp.}

Pure isolates were streaked on glucose yeast malt extract agar and incubated at $28^{\circ} \mathrm{C}$ for $7-10$ days. A loopful of an isolate was inoculated into glucose yeast malt extract broth and incubated at $28^{\circ} \mathrm{C}$ for more $7-10$ days under shaking condition $(190 \mathrm{rpm})$. After the incubation period, $1 \mathrm{ml}$ of the liquid culture was added into a sterile $1.5 \mathrm{ml}$ Eppendorf tube and centrifuged at 13,000 rpm for $5 \mathrm{~min}$ to precipitate the pellet at the bottom of the tube. The pellets were collected to make genomic DNA as described by Pitcher (Pitcher et al., 1989), following Guanidine thiocyanate DNA isolation method and using DNA isolation kit (Invitrogen, Pure Link (R) Genomic DNA Kit).

Purified genomic DNA $(3 \mu \mathrm{l})$ was run in an agarose gel electrophoresis $(60 \mathrm{ml}$ of $\times 1$ Tris Borate EDTA buffer, $0.6 \mathrm{~g}$ agarose) contained ethidium bromide $(4 \mu \mathrm{l})$. The following specific universal primers, $27 \mathrm{f}$ (5'-AGAGTTTGATCMTGGCTCAG-3') and 1525R (5'-AAGGAGGTGWTCCARCC-3') (Lane, 1991), were used to amplify 1500 base pairs the whole 16S rRNA gene (Chun and Goodfellow, 1995). Polymerase chain reaction (PCR) mixtures of $50 \mu \mathrm{l}$ were prepared. This stock was contained $1 \mu \mathrm{l}$ of the genomic DNA, $1 \mu \mathrm{l}$ of each primer, $25 \mu \mathrm{l}$ of GoTaq ${ }^{\circledR}$ Hot Start Colorless Master Mix, and $22 \mu \mathrm{l}$ of $\mathrm{ddH}_{2} \mathrm{O}$. Thermal cycler (MyGenie-96 Gradient Thermal Cycler, Korea) was used to amplify the $16 \mathrm{~S}$ rRNA gene under the following PCR condition (Shen et al., 2016); denaturation at $95^{\circ} \mathrm{C}$ for $15 \mathrm{~min} / 1$ cycle, denaturation at $95^{\circ} \mathrm{C}$ for $1 \mathrm{~min} / 35 \mathrm{cycle}$, annealing at $55^{\circ} \mathrm{C}$ for $1 \mathrm{~min} / 35$ cycle, extension at $72^{\circ} \mathrm{C}$ for $3 \mathrm{~min} / 35$ cycle, extension at $72^{\circ} \mathrm{C}$ for $10 \mathrm{~min} / 35 \mathrm{cycle}$, and holding at $25^{\circ} \mathrm{C}$ for $1 \mathrm{~min} / 1$ cycle. The PCR product $(3 \mu \mathrm{l})$ was run in $1 \%$ agarose gel electrophoresis $(60 \mathrm{ml}$ of $\times 1$ Tris Borate EDTA buffer,
0.6 g agarose) contained ethidium bromide ( $4 \mu \mathrm{l})$ to confirm the quality of the DNA [Figure 1]. The PCR product was then purified and sequenced with these sequencing primers; 518F (5'-CCAGCAGCCGCGGTAAT-3'), 800R (5'-TACCAGGGTATCTAATCC-3'), and Mg5f (5'-AAACTCAAAGGAATTGACGG-3'). Sequencing of the $16 \mathrm{~S}$ rRNA was carried out by Macrogen Company in Netherland. The sequenced 16S rRNA were compared with out-group Kitasatospora nipponensis HKI 0315T (AY442263) using ChromasPro (V2.1.3) (Kim et al., 2012). Phylogenetic dendrograms were drawn using the neighborhood-joining algorithm and the evolutionary distance matrix (Jukes and Cantor, 1969). EzTaxon server was used to find the closest strains to the tested strains using 1000 replicates and MEGA6 package program used for the phylogenetic analyzes (Tamura et al., 2013), while bootstrap analysis of the phylogenetic trees was done using Felsenstein (Felsenstein, 1985).

\section{RESULTS}

\section{Morphological and Physiological Characterization of Streptomyces spp.}

Melanin pigment formation on peptone-yeast extract iron agar, ability to produce diffusible pigment colors, substrate mycelial, and aerial spore mass on oatmeal agar was followed as some characters to identify the selected Streptomyces strains. Most of the researchers agree with that morphology is a suitable method to differentiate taxes (Gauze et al., 1957). Pigmentation was one of the primitive approaches to identify Streptomyces isolates (Pridham, 1958). Colony colors of the isolates were compared with the direct matching of color charts tables ISSC-NBS [Table 1 and Figure 1] (Shirling and Gottlieb, 1970). Based on this chart, gray, olive, and pink color groups were counted as Streptomyces genus. Only one isolate from each color group was selected to further study. The selected isolates were also studied to show their ability to utilize different carbon and nitrogen compounds [Table 2]. These data show that the strains utilize some or all of the nutritional sources. For example, both KS005 and KS010 utilized L-Histidine,

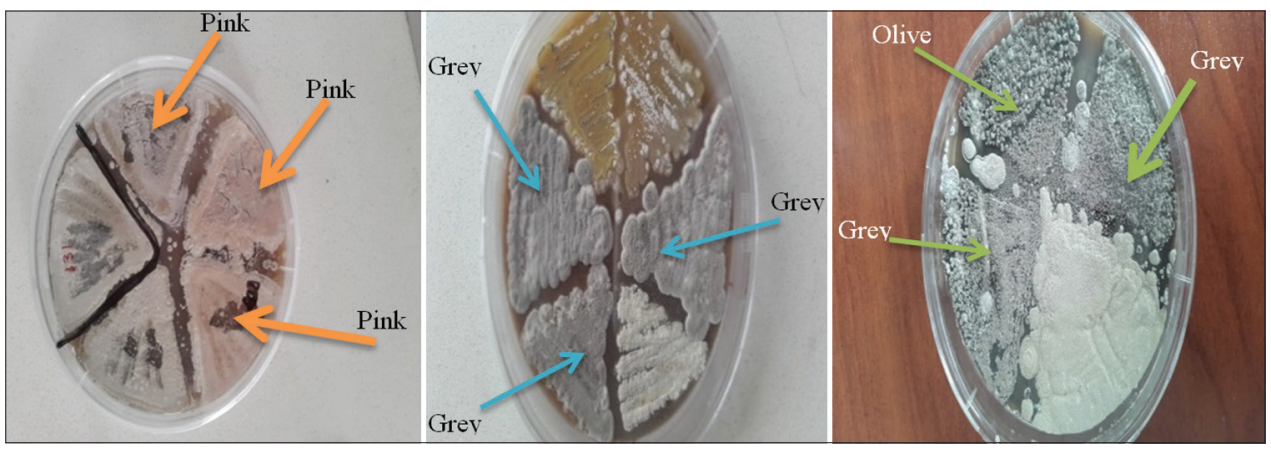

Figure 1: Selected isolated bacteria that were grown on oatmeal agar. These show three different colors on the basis of aerial and substrate mycelium. The samples were incubated for 7-10 days at $28^{\circ} \mathrm{C}$, KS010 (pink), KS005 (Gray), and KS007 (Olive) 
Table 1: Color grouping of the isolated bacteria

\begin{tabular}{llll}
\hline Bacterial isolates & Aerial spore mass & Colony reverse & Melanin pigmentation on peptone yeast extract iron agar \\
\hline $\mathrm{KS} 003, \mathrm{KS} 001, \mathrm{KS} 012$, and KS005 & Gray & Pale orange-yellow & None \\
$\mathrm{KS} 007, \mathrm{KS} 002, \mathrm{KS} 008$, and KS011 & Olive & Olive green & Yes \\
$\mathrm{KS} 010, \mathrm{KS} 009, \mathrm{KS} 006$, and KS004 & Pink & Light yellow & None \\
\hline
\end{tabular}

They were grown on peptone yeast extracts iron agar and oatmeal agar at $28^{\circ} \mathrm{C}$ for $7-10$ days. KS designates the source of the soil samples (Darband Ranya in Sulaimani governorate), 003 to 012 designate to the 12 sources of the soil collection areas

Table 2: Characteristics of Streptomyces isolates

\begin{tabular}{llll}
\hline Test strain microorganism & KS005 & KS007 & KS010 \\
Growth in sole nitrogen source & & & \\
Potassium nitrate & Positive & Negative & Positive \\
L-Tyrosine & Negative & Positive & Negative \\
L-Histidine & Positive & Negative & Positive \\
Growth in sole carbon source & & & \\
Dextran & Negative & Positive & Negative \\
D-Fructose & Positive & Positive & Positive \\
Lactose & Negative & Negative & Negative \\
D-Mannitol & Negative & Positive & Positive \\
D Raffinose & Positive & Positive & Positive \\
Sucrose & Negative & Negative & Negative \\
Maltose & Positive & Positive & Positive \\
D-Mannose & Negative & Positive & Negative \\
Sodium acetate & Positive & Positive & Positive \\
Sodium citrate & Positive & Negative & Positive \\
Pathogenic bacteria used to check antibacterial activity of the \\
isolates & & & \\
Klebsiella pneumoniae & Negative & Positive & Positive \\
Staphylococcus aureus & Positive & Positive & Positive \\
Pseudomonas fluorescens & Negative & Negative & Negative \\
Escherichia coli & Positive & Negative & Positive \\
Bacillus subtilis & Negative & Positive & Positive \\
Thermophilic bacteria & & & \\
$50{ }^{\circ} \mathrm{C}$ & Negative & Negative & Negative \\
\hline Growng & & &
\end{tabular}

Growing of the isolates in carbon and nitrogen sources, in high-temperature environment and growing with pathogenic bacteria

but KS007 strain was not able to utilize it, while KS007 used L-tyrosine instead. In addition, the behavior of the strains to inhibit the growth of $S$. aureus and B. subtilis Gram-positive and E. coli, Pseudomonas fluorescens, and Klebsiella pneumoniae Gram-negative bacteria were studied [Table 2 and Figure 2]. The isolates produced active antibacterial substances against all of the pathogens apart from P. fluorescens. Further study can be done to identify these antibacterial molecules. As another characterization, the strains were grown in high temperature $\left(50^{\circ} \mathrm{C}\right)$ so as to isolate thermophilic Streptomyces bacteria because most of the antimicrobial producer Streptomyces are life in high temperature (Place and Station, 1987). This result shows that none of the isolates can grow in this environment.

\section{Streptomyces spp. Identification using Conserved 16S rRNA}

The $16 \mathrm{~S}$ rRNA gene region was sequenced using sequenced primers 27f, 800r, and MG5f [Figure 3]. The sequenced data were aligned with the sequence data of

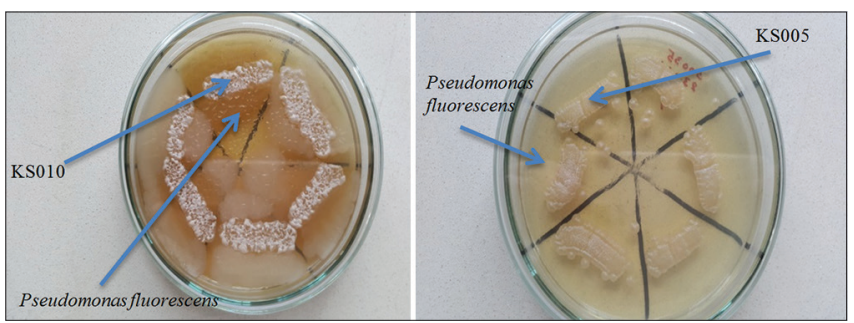

Figure 2: Antimicrobial activity of the isolates against pathogenic bacteria. KS005 and KS010 strains were grown on Muller-Hinton agar media incubated at $28^{\circ} \mathrm{C}$ for $4-7$ days and the pathogenic bacteria were then streaked to around test strains, incubated for more $48 \mathrm{~h}$ at $37^{\circ} \mathrm{C}$

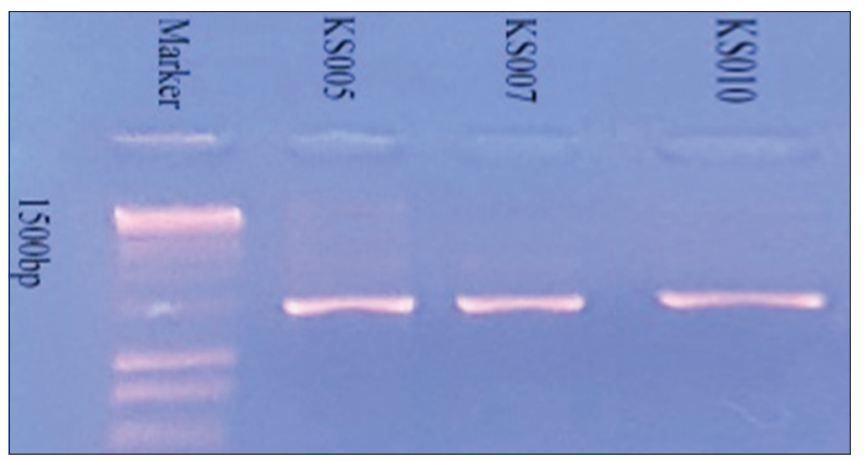

Figure 3: Agarose gel electrophoresis (1\%) of PCR products. The product was from amplified 16S rRNA gene marker

the closest related species which are in international databases using EzTaxon-e server to determine (\%) similarities. Phylogenetic analysis showed that the new strains were cluster with reference Streptomyces spp. The 16S rRNA gene of the tested KS005 and KS007 strains had the highest sequence similarities $(99.32 \%)$ with their type strain Streptomyces lateritius, while KS010 was closely related to Streptomyces atrovirens with a high identity of 99.32\% [Figures 4 and 5]. Along with the physiological and morphological properties, the phylogenetic analyses have also provided crucial evidence that the tested strains are belong to Streptomyces genus.

\section{DISCUSSION}

There are some antibiotic-resistant microbes that have become universal health problems, especially in developing countries (Mazel and Davies, 1999). This study worked toward to isolate and characterize Streptomyces from distinct habitats in Sulaimani governorate so as to identify Streptomyces 


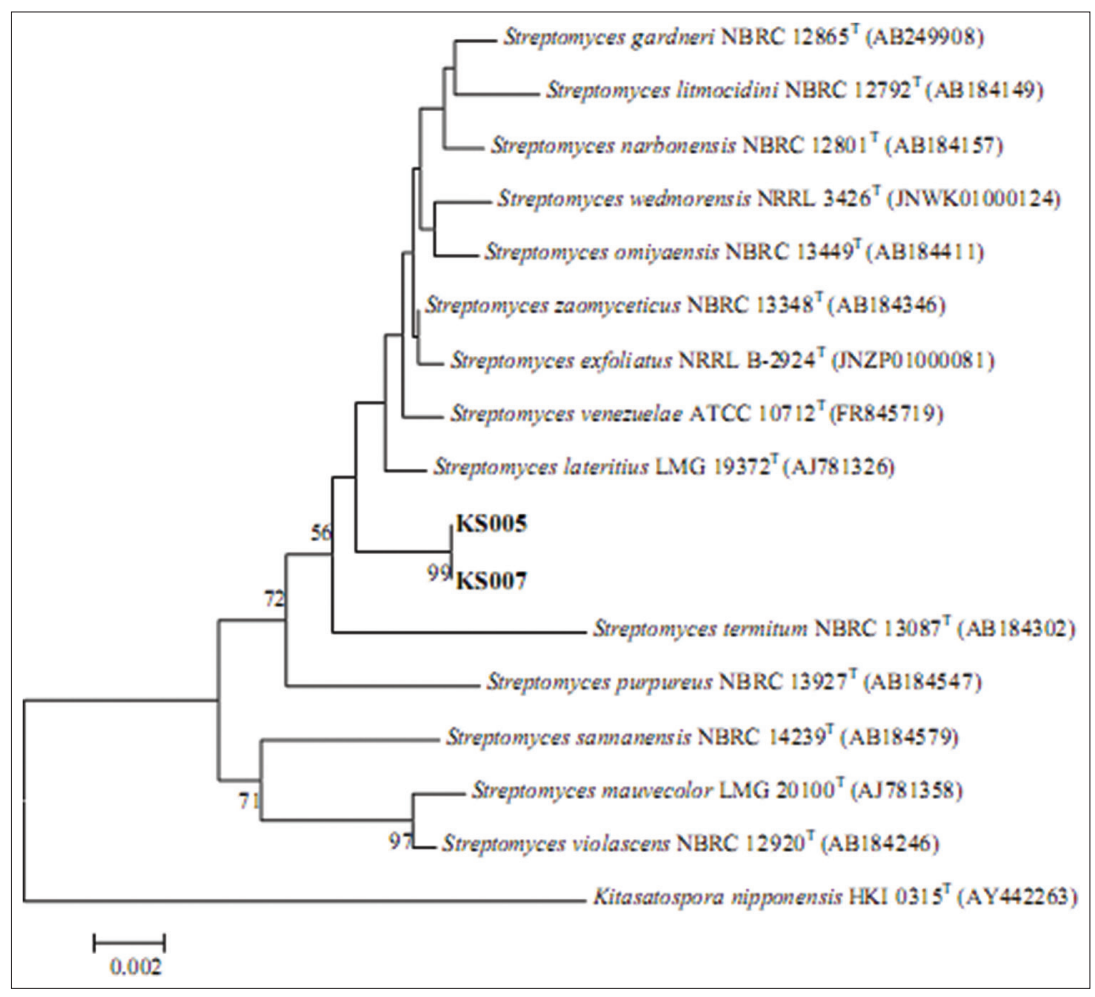

Figure 4: Phylogenetic dendrogram comparison of KS005 and KS007 tested strains with references strains. Complete sequence $16 \mathrm{~S}$ rRNA gene of reference strains was downloaded from GenBank to align with the new strains using dendrogram neighbor-joining algorithms. The dendrogram and numbers at nodes detected the level of bootstrap support, only value $\geq 56 \%$ is shown. The $16 \mathrm{~S}$ rDNA

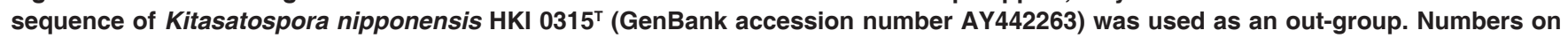
the branches indicate Bootstrap percentage after 1000 replications during constructing the phylogenetic tree. Scale bar refers to a phylogenetic distance of 0.002 nucleotide substitutions per site

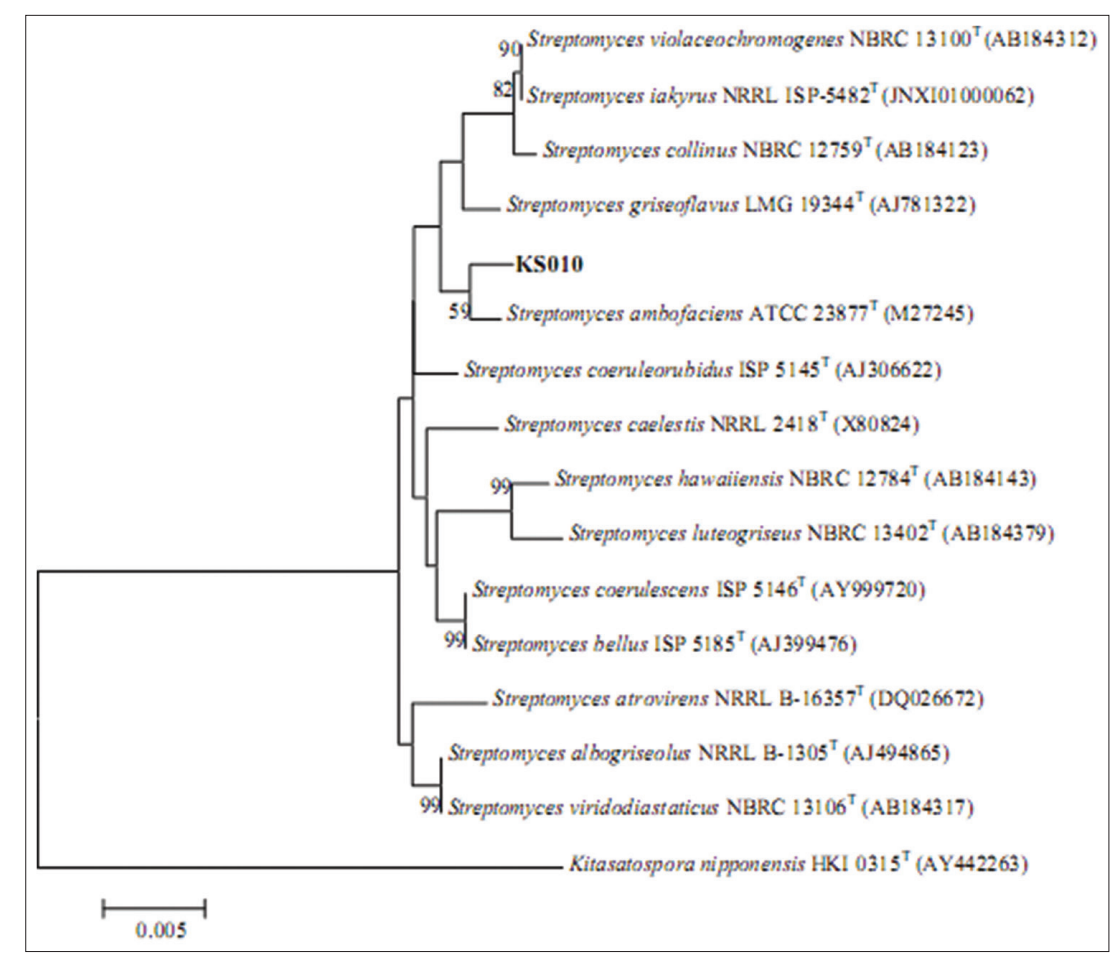

Figure 5: Phylogenetic dendrogram comparison of KS010 isolate with references strains. Dendrogram produced neighbor-joining algorithms and numbers at nodes detect the level of bootstrap support (\%), only value $\geq 59 \%$ is shown. The $16 \mathrm{~S}$ rDNA sequence of Kitasatospora nipponensis HKI $0315^{\top}$ (GenBank accession numbers AY442263) was used as an out-group. Numbers on the branches indicate Bootstrap percentage after 1000 replications during constructing the phylogenetic tree. Scale bar refers to a phylogenetic distance of 0.005 nucleotide substitutions per site 
strains. As two crucial properties, morphological characters of colonies such as pigmentation and antimicrobial activity were followed for initial identification of the selected strains. In addition, it is reported that $16 \mathrm{~S} r \mathrm{RNA}$ gene is stable, ubiquitous, and conserved subject to horizontal gene transfer (Stackebrandt et al., 2002). Therefore, it is an effective molecular marker for the primary key for phylogeny-based identification of archaea and bacteria (Kim et al., 2012; Olsen and Woese, 1993; Stackebrandt et al., 2002; Tindall et al., 2010). The phylogenetic analysis revealed that KS010 strain is closely related to $S$. atrovirens based on the highest identity $(99.32 \%)$, while KS005 and KS007 strains were close to S. lateritius. These phenotypic and genotypic properties have provided evidence that all of these three strains are belonging to Streptomyces genus. Furthermore, KS010 isolate can make an inhibition zone against all the pathogenic Gram-negative and Grampositive bacteria except P. fluorescens, and KS005 and KS007 strains have shown antibacterial activity against $S$. aureus. This might relate to these isolates can make a useful type of bioactive compounds against pathogenic organisms (Mao et al., 2011; Balachandran et al., 2015).

\section{CONCLUSION}

This study has shown several Streptomyces strains which were isolated from specific environmental habitats of Darband Ranya in Sulaimani governorate. All of the physiological and phylogenetic analysis have provided evidence that KS005, KS007, and KS010 strains are belong to the genus Streptomyces. The isolates also have made antibacterial compound against most of the tested pathogens. This behavior plus biochemical properties suggesting that this microorganism might be adapted to survive in a specific environment. Further characterizations of the three Streptomyces are necessary to confirm that they are novel strains. Additional studies can be done to isolate and identify more Streptomyces genera from the studied areas following the DNA-DNA hybridization technique.

\section{REFERENCES}

Atalan, E. 1993. Selective Isolation, Characterisation and Identification of Some Streptomyces Species.

Balachandran, C., V. Duraipandiyan, Y. Arun, B. Sangeetha, N. Emi, N. A. Al-Dhabi and S. Ignacimuthu. 2016. Isolation and characterization of 2-hydroxy-9, 10-anthraquinone from Streptomyces olivochromogenes (ERINLG-261) with antimicrobial and antiproliferative properties. Rev. Bras. Farmacogn. 26(3): 285-295.

Balachandran, C., V. Duraipandiyan1, N. Emi and S. Ignacimuthu. 2015. Antimicrobial and cytotoxic properties of Streptomyces sp (ERINLG-51) isolated from Southern Western Ghats. South Indian J. Biol. Sci. 1: 7-14.

Belghit, S., E. H. Driche, C. Bijani, A. Zitouni, N. Sabaou, B. Badji and
F. Mathieu. 2016. Activity of 2, 4-Di-tert-butylphenol produced by a strain of Streptomyces mutabilis isolated from a Saharan soil against Candida albicans and other pathogenic fungi. J. Mycol. Med. 26: 160-169.

Bérdy, J. 2005. Bioactive microbial metabolites. J. Antibiot. 58(1): 1-26.

Bunyapaiboonsri, T., S. Lapanun, S. Supothina, P. Rachtawee, S. Chunhametha, C. Suriyachadkun, T. Boonruangprapa, P. Auncharoen, C. Chutrakul and V. Vichai. 2016. Polycyclic tetrahydroxanthones from Streptomyces chrestomyceticus BCC 24770. Tetrahedron. 72(5): 775-778.

Chun, J. and M. Goodfellow. 1995. A phylogenetic analysis of the genus Nocardia with 16S rRNA gene sequences. Int. J. Syst. Bacteriol. 45: 240-245.

Dastager, S. G. and L. Sunil. 2016. Streptomyces lonarensis sp. nov., isolated from Lonar Lake, a meteorite salt water lake in India. Antonie Van Leeuwenhoek. 109(2): 225-235.

Dyson, P. 2011. Streptomyces: Molecular Biology and Biotechnology. Caister Academic Press, Norwich.

El-Naggar, N.E.A. 2015. Isolation, screening and identification of actinobacteria with uricase activity: Statistical optimization of fermentation conditions for improved production of uricase by Streptomyces rochei NEAE-25. Int. J. Pharmacol. 11(7): 644658.

Felsenstein, J. 1985. Confidence limits on phylogenies: An approach using the bootstrap. Evolution. 39: 783-791.

Flärdh, K. and M. Buttner. 2009. Streptomyces morphogenetics: Dissecting differentiation in a filamentous bacterium. Nat. Rev. 7: $36-49$.

Gauze, G. F., T. P. Preobrazhenskaya, E. S. Kudrina, N. O. Blinov, I. D. Ryabova and M. A. Sveshnikova. 1957. Problems in the Classification of Antagonistic Actinomycetes.

Glauert, M. 1961. The fine structure of Streptomyces violaceoruber (S. coelicolor). III. The walls of the mycelium and spores. J. Biophys. Biochem. Cytol. 10(4): 505-516.

Hasani, A., A. Kariminik and K. Issazadeh. 2014. Streptomycetes: Characteristics and their antimicrobial activities. Int. J. Adv. Biol. Biomed. Res. 2(1): 63-75.

Hopwood, D. 2007. Streptomyces in Nature and Medcine. Oxford University Press, Oxford.

Jukes, T. H. and C. Cantor. 1969. Evolution of protein molecules. In: Mammalian Protein Metabolism. Academic Press, New York. p21-132.

Jüttner, F. and S. B. Watson. 2007. Biochemical and ecological control of geosmin and 2-methylisoborneol in source waters. Appl. Environ. Microbiol. 73: 4395-4406.

Kim, O. S., Y. J. Cho, K. Lee, S. H. Yoon, M. Kim, H. Na, S. C. Park, Y. S. Jeon, J. Lee, H. Yi, S. Won and J. Chun. 2012. Introducing EzTaxon-e: A prokaryotic 16S rRNA gene sequence data base with phylotypes that represent uncultured species. Int. J. Syst. Evol. Microbiol. 62: 716-721.

Korn-Wendisch, F. and H. Kutzner. 1992. The family Streptomycetaceae. In: Balows, A., H. G. Truper, M. Dworkin, W. Harder, and K. H. Schleifer, editors. The Prokaryotes. Springer, Berlin.

Lane, D. 1991. 16S/23S rRNA sequencing. In: Nucleic Acid Techniques in Bacterial Systematics. John Wiley \& Sons, Inc., New York.

Lounes, A., A. Lebrihi, C. Benslimane, G. Lefebvre and P. Germain. 1996. Regulation of spiramycin synthesis in Streptomyces ambofaciens: Effects of glucose and inorganic phosphate. Appl. Microbiol. Biotechnol. 45(1-2): 204-211. 
Madhusudhan, D. N., B. B. Z. Mazhari, S. G. Dastager and D. Agsar. 2014. Production and cytotoxicity of extracellular insoluble and droplets of soluble melanin by Streptomyces lusitanus DMZ-3. Biomed. Res. Int. 2014: 306895.

Maleki, H., A. Dehnad, S. Hanifian and S. Khani. 2013. Isolation and molecular identification of Streptomyces spp. with antibacterial activity from northwest of Iran. Bioimpacts. 3(3): 129-134.

Mao, J., J. Wang, H. Q. Dai, Z. D. Zhang, Q. Y. Tang, B. Ren, N. Yang, M. Goodfellow, L. X. Zhang and Z. Liu. 2011. Yuhushiella deserti gen. nov., sp. nov., a new member of the suborder Pseudonocardineae. Int. J. Syst. Evol. Microbiol. 61: 621-630.

Mazel, D. and J. Davies. 1999. Antibiotic resistance in microbes. Cell. Mol. Life Sci. 56(9-10): 742-754.

Mokrane, S., N. Bouras, N, Sabaou and F. Mathieu. 2013. Actinomycetes from saline and non-saline soils of Saharan palm groves: Taxonomy, ecology and antagonistic properties. Afr. J. Microbiol. Res. 7(20): 2167-2178.

Olsen, G. J. and C. R. Woese. 1993. Ribosomal RNA: A key to phylogeny. FASEB J. 7: 113-123.

Pitcher, D. G., N. A. Saunders and R. Owen. 1989. Rapid extraction of bacterial genomic DNA with guanidium thiocyanate. Lett. Appl. Microbiol. 8: 151-156.

Place, F. and R. E. Station. 1987. Numerical classification of thermophilic streptomycetes. J. Gen. Microbiol. 133: 3135-3149.

Pridham, T. G., C. W. Hesseltine and R. G. Benedict. 1958. A guide for the classification of streptomycetes according to selected groups; placement of strains in morphological sections. Appl. Microbiol. 6: 52-79.

Rafieenia, R. 2013. Effect of nutrients and culture conditions on antibiotic synthesis in streptomycetes. Asian J. Pharm. Health Sci. 3(3): 810-821.

Rambabu, V., S. Suba and S. Vijayakumar. 2015. Antimicrobial and antiproliferative prospective of kosinostatin-a secondary metabolite isolated from Streptomyces sp. J. Pharm. Anal. 5(6): 378-382.

Sánchez, S., A. Chávez, A. Forero, Y. García-Huante, A. Romero, M. Sánchez, D. Rocha, B. Sánchez, M. Avalos, S. GuzmánTrampe, R. Rodríguez-Sanoja, E. Langley and B. Ruiz. 2010. Carbon source regulation of antibiotic production. J. Antibiot.
63(8): 442-459.

Sanghvi, G. V., D. Ghevariya, S. Gosai, R. Langa, N. Dhaduk, P. D. Kunjadia, D. J. Vaishnav and G. S. Dave. 2014. Isolation and partial purification of erythromycin from alkaliphilic Streptomyces werraensis isolated from Rajkot, India. Biotechnol Rep. 1-2: 2-7.

Shen, T., C. Wang, H. Yang, Z. Deng, S. Wang and B. Shen. 2016. Identification, solid-state fermentation and biocontrol effects of Streptomyces hygroscopicus B04 on strawberry root rot. Appl. Soil Ecol. 103: 36-43.

Shirling, E. B. and D. Gottlieb. 1970. Report of the international Streptomyces project. Five years collaborative research. In: Prauser, H., editor. The Actinomycetales. Wiley, Hoboken.

Stackebrandt, E., W. Frederiksen, G. M. Garrity, P. A. Grimont, P. Kampfer, M. C. Maiden, X. Nesme, R. Rossello-Mora, J. Swings, H. G. Truper, L. Vauterin, A. C. War and W. Whitman. 2002. Report of the ad hoc committee for the re-evaluation of the species definition in bacteriology. Int. J. Syst. Evol. Microbiol. 52: 1043-1047.

Staneck, J. L. and Roberts, G. D. 1974. Simplified approach to identification of aerobic actinomycetes by thin-layer chromatography. Appl. Microbiol. 28(2): 226-231.

Tamura, K., G. Stecher, D. Peterson, A. Filipski and S. Kumar. 2013. MEGA6: Molecular evolutionary genetics Analysis version 6.0. Mol. Biol. Evol. 30(12): 2725-2729.

Tatar, D. and Sahin, N. 2015. Streptomyces seymenliensis sp. nov., isolated from soil. Antonie Van Leeuwenhoek. 107: 411-418.

Tindall, B. J., R. Rossello-Mora, H. J. Busse, W. Ludwig and P. Kampfer. 2010. Notes on the characterization of prokaryote strains for taxonomic purposes. Int. J. Syst. Evol. Microbiol. 60: 249-266.

Ventura, M., C. Canchaya, A. Tauch, G. Chandra, G. F. Fitzgerald, K. F. Chater and D. van Sinderen. 2007. Genomics of Actinobacteria: Tracing the evolutionary history of an ancient phylum. Microbiol. Mol. Biol. Rev. 71: 495-548.

Vickers, J. C. and S. Williams. 1987. An assessment of plate inoculation procedures for the enumeration and soil isolation of soil streptomycetes. Microbic. Lett. 35: 113-117.

Waksman, S. A. and A. T. Henrici. 1943. The nomenclature and classification of the actinomycetes. J. Bacteriol. 46: 337-341. 